\title{
Ideal Dasar Prima dalam Aljabar Atas Suatu Ring Komutatif
}

\author{
Khurul Wardati \\ Program Studi Pendidikan Matematika, Fakultas Sains dan Teknologi, UIN Sunan Kalijaga, Jl. Marsda \\ Adisucipto No. 1 Yogyakarta, Indonesia
}

Korespondensi; Email: khurulwardati@gmail.com

\begin{abstract}
Abstrak
Definisi ideal dasar dan ideal bebas dalam aljabar bebas atas ring komutatif dengan elemen satuan adalah ekuivalen. Namun, ideal dasar dalam suatu aljabar tak bebas belum tentu merupakan ideal bebas, sementara ideal bebas pasti ideal dasar. Artikel ini membahas beberapa sifat ideal dasar prima dalam aljabar tak bebas atas ring komutatif dengan elemen satuan.
\end{abstract}

Kata Kunci: aljabar tak bebas; ideal bebas; ideal dasar; ideal dasar prima

\begin{abstract}
The definitions of basic ideal and free ideal in free algebras over a unital commutative ring are equivalent. However, a basic ideal in the non-free algebra is not necessarily a free ideal, while any free ideal is definitely a basic ideal. This paper will discuss some properties of prime basic ideal in non-free algebras over a unital commutative ring.
\end{abstract}

Keywords: basic ideal; free ideal; non-free algebra; prime basic ideal

\section{Pendahuluan}

Aljabar atas lapangan merupakan ruang vektor, sehingga aljabar atas lapangan pasti memiliki basis. Sebarang subruang vektor pasti memiliki basis, demikian pula ideal dari aljabar atas lapangan juga mempunyai basis. Analogi perumuman ruang vektor ke modul, aljabar atas lapangan dapat diperumum atas ring komutatif dengan elemen satuan. Salah satu akibat perumuman ini adalah bahwa aljabar atas ring komutatif dengan elemen satuan belum tentu mempunyai basis. Aljabar yang mempunyai basis disebut aljabar bebas

Berdasarkan [4], aljabar lintasan Leavitt atas ring komutatif $R$ dengan elemen satuan selalu merupakan $R$-aljabar bebas. Aljabar ini merupakan perumuman dari aljabar lintasan Leavitt atas lapangan. Temuan penting dalam [4] adalah didefinisikannya ideal dasar dalam $R$-aljabar lintasan Leavitt. Definisi ideal dasar diperumum [2] dalam $R$-aljabar bebas atas ring komutatif dengan elemen satuan, sehingga dapat diimplementasikan dalam aljabar lintasan atas $R$.

Jika $A$ adalah aljabar atas lapangan $F$, maka sebarang ideal $I$ di $A$ berlaku: $k x \in I \Rightarrow x \in I$ untuk setiap $k \in F \backslash\{0\}$ dan setiap $x \in X$ dengan $X$ sebarang basis dari $A$. Hal ini, dikarenakan setiap elemen tak nol di lapangan $F$ selalu mempunyai invers. Sifat tersebut belum tentu berlaku untuk suatu ideal di $R$-aljabar bebas atas ring komutatif dengan elemen satuan. Wardati, dkk. ([2]) telah mendefinisikan Ideal $I$ dalam $R$-aljabar bebas $A$ atas ring komutatif dengan elemen satuan, disebut ideal dasar, jika berlaku $r x \in I \Rightarrow x \in I$ untuk setiap $r \in R \backslash\{0\}$ dan setiap $x \in X$ dengan $X$ sebarang basis dari $R$-aljabar bebas $A$. Tampak bahwa setiap ideal dalam aljabar atas lapangan merupakan idel dasar.

Sub-aljabar dari aljabar atas lapangan selalu merupakan aljabar bebas dengan basisnya merupakan subhimpunan suatu basis dari aljabarnya. Akan tetapi sub-aljabar dari aljabar bebas atas ring komutatif dengan elemen satuan, belum tentu merupakan aljabar bebas. Wardati, dkk. ([3]) mendefinisikan ideal 
bebas (free ideal) $I$ dalam $R$-aljabar bebas $A$ atas ring komutatif dengan elemen satuan, jika $I$ merupakan $R$-subaljabar bebas dengan basis subhimpunan dari suatu basisnya $A$. Artinya, ideal dalam $R$-aljabar bebas meskipun merupakan $R$-subaljabar bebas belum tentu merupakan ideal bebas. Berdasarkan [3, Teorema 2.8], bahwa sebarang ideal dalam aljabar bebas merupakan ideal bebas jika dan hanya jika ideal tersebut merupakan ideal dasar.

Himpunan bilangan rasional $\mathbb{Q}$ merupakan lapangan, sehingga $\mathbb{Q}$ dapat dipandang sebagai ruang vektor atas dirinya sendiri. Selain itu, $\mathbb{Q}$ juga dapat dipandang sebagai $\mathbb{Z}$-modul dan sekaligus $\mathbb{Z}$ aljabar, karena $\mathbb{Q}$ adalah grup abelian aditif. Perhatikan bahwa untuk setiap bilangan bulat tak nol $m, Q_{m}=\left\{\frac{1}{x} \mid x \in m \mathbb{Z}, x \neq 0\right\} \subset \mathbb{Q}$ membangun $\mathbb{Q}$ karena untuk setiap $\frac{p}{q} \in \mathbb{Q}$ dapat dinyatakan sebagai kombinasi linear dari elemen-elemen dalam $\mathbb{Q}_{m}$ yaitu $\frac{p}{q}=m\left(\frac{1}{m q}\right)+2 m(p-1)\left(\frac{1}{2 m q}\right)$. Akan tetapi, $\mathbb{Q}_{m}$ tidak bebas linear karena terdapat koefisien tak nol dalam $\mathbb{Z}$ sehingga

$$
2\left(\frac{1}{2}\right)+(-4)\left(\frac{1}{4}\right)+0\left(\frac{1}{6}\right)+0\left(\frac{1}{8}\right)=0
$$

Jadi, $\mathbb{Q}_{m}$ bukan basis dari $\mathbb{Z}$-aljabar $\mathbb{Q}$. Setiap bilangan rasional tak nol $\frac{a}{b}, \frac{c}{d}$ saling bergantung linear dikarenakan terdapat bilangan bulat $m=b c, n=-a d$ sehingga $m \frac{a}{b}+n \frac{c}{d}=0$. Hal ini berarti bahwa $\mathbb{Z}$-aljabar $\mathbb{Q}$. tidak mempunyai basis, sehingga $\mathbb{Q}$ merupakan $\mathbb{Z}$-aljabar tak bebas.

Karena $\mathbb{Q}$ lapangan maka ideal dari $\mathbb{Z}$-aljabar $\mathbb{Q}$ hanyalah ideal nol dan dirinya sendiri. Ambil sebarang bilangan bulat tak nol $m$, maka selalu berlaku bahwa setiap $y \in \mathbb{Q}_{m}$ dan setiap $0 \neq a \in \mathbb{Z}$, $a y \in\{0\} \Longrightarrow y \in\{0\}$ karena antisedennya selalu salah. Hal ini menginspirasikan bahwa definisi ideal dasar dapat diperumum pada $R$-aljabar tak bebas dengan melibatkan pembangun aljabarnya yang tidak harus merupakan basis. Perumuman ini berimplikasi perlunya diselidiki sifat-sifat ideal dasar pada $R$ aljabar tak bebas tersebut.

Berdasarkan ideal dasarnya, telah didefinisikan sifat sederhana mendasar (basically simple) aljabar lintasan Leavitt atas ring komutatif dengan elemen satuan, sebagai aljabar bebas yang ideal dasarnya hanyalah ideal nol dan dirinya sendiri ([4]). Berdasarkan sifat ini, telah didefinisikan dalam [1] tentang sifat ideal dasar minimal, prima dan semiprima yang secara berurutan mengkarakterisasi aljabar lintasan Leavitt atas ring komutatif dengan elemen satuan, yang semisederhana mendasar (basically semisimple), prima mendasar (basically prime) dan semiprime mendasar (basically semiprime) dengan merujuk [6] dan [7].

Penelitian terus berlanjut pada aljabar bebas atas ring komutatif unital. Sifat-sifat ideal dasar minimal yang mengkarakterisasi aljabar semisederhana mendasar telah dikaji dalam [3], sedangkan keprimaan mendasar aljabar tersebut berdasarkan sifar ideal dasar prima dibahas dalam [2]. Artikel ini akan membahas beberapa sifat ideal dasar prima pada aljabar tak bebas atas ring komutatif dengan elemen satuan, setelah dikaji ideal dasar dan ideal bebas dalam aljabar tersebut.

\section{Perumuman Ideal Dasar dan Ideal Bebas dalam Aljabar Atas Ring Komutatif Unital}

Definisi ideal prima dalam [6] dan [7] mensyaratkan ring (aljabar)nya dengan elemen satuan. Oleh karenanya, ruang lingkup dalam artikel ini adalah aljabar unital.

Definisi 2.1 [8]

Diberikan ring komutatif $R$ dengan elemen satuan. Himpunan tak kosong $A$ disebut $R$-aljabar jika $A$ merupakan ring sekaligus $R$-modul (kiri). Aljabar $A$ dikatakan $R$-aljabar unital jika $A$ memiliki elemen satuan $1_{A}$. Jika diberikan sub-subhimpunan tak kosong $S, I \subseteq A$, maka $S$ dikatakan $R$-subaljabar dari $A$, jika $S$ subring dari $A$ dan $S$ merupakan $R$-submodul dari $A$. Subhimpunan $I$ dikatakan ideal dari $R$-aljabar $A$, jika $I$ ideal dari ring $A$ dan $I$ merupakan $R$-submodul dari $R$-modul $A$.

Grillet [5] mendefinisikan suatu $R$-aljabar (unital) $A$ dikatakan $R$-aljabar bebas (free $R$-algebra), jika $A$ merupakan $R$-modul bebas, yang artinya modul $A$ mempunyai basis. Jika $R$-aljabar bebas $A$ 
mempunyai basis $X$ maka $A$ dibangun oleh $X$ dinotasikan $A=\langle X\rangle$ dengan $X$ bebas linear. Perlu kiranya diingatkan kembali pengertian ideal dasar dalam $R$-aljabar bebas.

\section{Definisi 2.2 [3]}

Diberikan $R$-aljabar bebas $A$. Suatu ideal $I$ di $A$ dikatakan ideal dasar, jika untuk setiap basis $X$ dari $A$ berlaku: untuk setiap elemen tak nol $k \in R$ dan setiap $x \in X$, jika $k x \in I$ maka $x \in I$.

Jika $X$ basis dari $R$-aljabar bebas $A$ maka setiap elemen tak nol $k \in R$ dan setiap $x \in X$, berlaku $k x \neq 0$. Berdasarkan Definisi 2.2, ideal nol selalu merupakan ideal dasar. Hal ini berakibat bahwa sebarang $R$-aljabar bebas $A$ mempunyai dua ideal dasar trivial, yaitu ideal nol dan dirinya sendiri sebagaimana telah dikaji dalam [3].

Contoh 2.3 Diberikan $\mathbb{Z}_{6}$-aljabar bebas $M=\left(\begin{array}{cc}\mathbb{Z}_{6} & \mathbb{Z}_{6} \\ 0 & \mathbb{Z}_{6}\end{array}\right)$ maka ideal $I=\left(\begin{array}{cc}\mathbb{Z}_{6} & \mathbb{Z}_{6} \\ 0 & 0\end{array}\right)$ merupakan ideal dasar. Akan tetapi, ideal $J=\left(\begin{array}{cc}2 \mathbb{Z}_{6} & 2 \mathbb{Z}_{6} \\ 0 & 2 \mathbb{Z}_{6}\end{array}\right)$ bukan ideal dasar, karena $2\left(\begin{array}{ll}1 & 0 \\ 0 & 0\end{array}\right)=\left(\begin{array}{ll}2 & 0 \\ 0 & 0\end{array}\right) \in J$ tetapi $\left(\begin{array}{ll}1 & 0 \\ 0 & 0\end{array}\right) \notin J$.

Ideal $J$ dalam Contoh 2.3 merupakan $\mathbb{Z}_{6}$-subaljabar tidak bebas dari $M$. Hal ini membuktikan bahwa tidak semua subaljabar dari aljabar bebas atas ring komutatif dengan elemen satuan merupakan aljabar bebas. Akan tetapi, ideal $I$ merupakan $\mathbb{Z}_{6}$-subaljabar bebas dari $M$ dengan basis $\left\{\left(\begin{array}{ll}1 & 0 \\ 0 & 0\end{array}\right),\left(\begin{array}{ll}0 & 1 \\ 0 & 0\end{array}\right)\right\}$, yang merupakan subset dari suatu basis di $M$. Perhatikan bahwa ideal $2 \mathbb{Z}$ merupakan $\mathbb{Z}$-subaljabar bebas dari aljabar bebas $\mathbb{Z}$ atas dirinya sendiri. Namun, basis dari $3 \mathbb{Z}$ adalah singleton $\{3\}$ atau $\{-3\}$ yang bukan merupakan subset dari sebarang basis aljabar $\mathbb{Z}$. Hal ini menginspirasikan perlunya didefinisikan ideal yang sekaligus merupakan subaljabar bebas dengan basis subset dari suatu basis aljabarnya.

\section{Definisi 2.4 [3]}

Diberikan $R$-aljabar bebas $A$. Ideal $I$ di $A$ dikatakan ideal bebas, jika $I$ merupakan $R$-submodul bebas dari $A$ dengan basis subset dari suatu basis dari $A$.

Berdasarkan Definisi 2.4, ideal nol selalu merupakan ideal bebas karena ideal nol merupakan subaljabar bebas dengan basis himpunan kosong. Ideal dasar I dalam Contoh 2.3 merupakan ideal bebas, sedangkan ideal $J$ bukan ideal dasar sekaligus bukan ideal bebas. Ideal $2 \mathbb{Z}$ dalam $\mathbb{Z}$ bukan merupakan ideal bebas meskipun $2 \mathbb{Z}$ merupakan $\mathbb{Z}$-submodul bebas. Telah dibuktikan secara lengkap dalam [3, Teorema 2.8] bahwa ideal $I$ dalam $R$-aljabar bebas $A$ merupakan ideal dasar jika dan hanya jika $I$ merupakan ideal bebas di $A$.

Himpunan $M$ dalam Contoh 2.3 dapat dipandang sebagai $\mathbb{Z}$-aljabar tak bebas dengan $I$, $J$ keduanya tetap merupakan ideal dari $M$. Jika $R$-aljabar $A$ dibangun oleh $X \subset A$ yang tak bebas linear maka tidak selalu berlaku bahwa setiap elemen tak nol $r \in R$ dan setiap elemen $x \in X, r x \neq 0$. Hal inilah yang memotivasi perumuman ideal dasar dalam aljabar tak bebas.

\section{Definisi 2.5}

Diberikan $R$-aljabar $A=\langle X\rangle$. Ideal $I$ di $A$ dikatakan ideal dasar, jika untuk setiap elemen tak nol $r \in R$ dan setiap $x \in X$, berlaku jika $0 \neq r x \in I$ maka $x \in I$.

Perlu dipertegas bahwa $R$-aljabar $A=\langle X\rangle=\left\{\sum_{i=1}^{m} r_{i} x_{i}: r_{i} \in R, x_{i} \in X, m \in N\right\}$ dengan $X \subset A$ tidak harus bebas linear untuk Definisi 2.5. Penegasan inilah yang memperlihatkan perumuman Definisi 2.5 dari Definisi 2.2. Jika $I=\{0\}$ maka antiseden dalam Definisi 2.5 selalu salah, sehingga berakibat bahwa ideal nol selalu merupakan ideal dasar.

\section{Akibat 2.6}

Sebarang $R$-aljabar $A$ selalu memiliki dua ideal dasar trivial yaitu ideal nol dan $A$ itu sendiri. 
Contoh 2.7 Diberikan $\mathbb{Z}$-aljabar $M=\left(\begin{array}{cc}\mathbb{Z}_{6} & \mathbb{Z}_{6} \\ 0 & \mathbb{Z}_{6}\end{array}\right)=\langle X\rangle$ dengan $X=\left\{\left(\begin{array}{ll}1 & 0 \\ 0 & 0\end{array}\right),\left(\begin{array}{ll}0 & 1 \\ 0 & 0\end{array}\right),\left(\begin{array}{ll}0 & 0 \\ 0 & 1\end{array}\right)\right\}$ tak bebas linear. Ideal $I=\left(\begin{array}{cc}\mathbb{Z}_{6} & \mathbb{Z}_{6} \\ 0 & 0\end{array}\right)$ merupakan ideal dasar, dan $J=\left(\begin{array}{cc}2 \mathbb{Z}_{6} & 2 \mathbb{Z}_{6} \\ 0 & 2 \mathbb{Z}_{6}\end{array}\right)$ bukan ideal dasar, dengan alasan serupa pada Contoh 2.3.

Tampak jelas dari Contoh 2.7, adanya elemen pembangun $\left(\begin{array}{ll}1 & 0 \\ 0 & 0\end{array}\right)$ dan bilangan bulat 6 dengan $6\left(\begin{array}{ll}1 & 0 \\ 0 & 0\end{array}\right)=\left(\begin{array}{ll}0 & 0 \\ 0 & 0\end{array}\right)$ membuktikan salah satu sifat yang tidak bertahan dalam $R$-aljabar tak bebas. Lihat kembali ideal-ideal $I, J$ dalam $\mathbb{Z}$-aljabar $M$. Ideal $I$ dibangun oleh $\left\{\left(\begin{array}{ll}1 & 0 \\ 0 & 0\end{array}\right),\left(\begin{array}{ll}0 & 1 \\ 0 & 0\end{array}\right)\right\}=X \cap I$ Akan tetapi, pembangun dari ideal $J$ adalah $\left\{\left(\begin{array}{ll}2 & 0 \\ 0 & 0\end{array}\right),\left(\begin{array}{ll}0 & 2 \\ 0 & 0\end{array}\right),\left(\begin{array}{ll}0 & 0 \\ 0 & 2\end{array}\right)\right\} \not \subset X$ bahkan pembangun dari $J$ juga bukan subset untuk sebarang pembangun dari $M$. Hal ini menginspirasikan sifat dari ideal dasar dalam $R$-aljabar tak bebas berikut.

\section{Lemma 2.8}

Diberikan ideal dasar $I$ dari $R$-aljabar $A$ dan $X$ sebarang pembangun dari $A$, maka berlaku:

1. Untuk setiap $x \in X, x \in I$ jika dan hanya jika $x$ merupakan suatu elemen pembangun dari $I$ sebagai $R$-submodul dari $A$;

2. Untuk setiap elemen tak nol $r_{i} \in R$ dan setiap $x_{i} \in X$ dengan $i=1,2, \ldots, n$ untuk suatu $n \in N$, jika $0 \neq \sum_{i=1}^{n} r_{i} x_{i} \in I$ maka $x_{i} \in I$ untuk setiap $i$;

3. Ideal dasar $I=\left\langle X_{I}\right\rangle$ dengan $X_{I}=X \cap I$.

Bukti: Ambil sebarang $x \subset A$ sedemikian sehingga $R$-aljabar $A=\langle X\rangle$. Misalkan $I$ ideal dasar dari $A$, maka:

1. $(\Longrightarrow)$ Ambil sebarang $x \in X$ sedemikian sehingga $x \in I$. Andaikan bahwa $x$ bukan merupakan suatu elemen pembangun dari $I$ sebagai $R$-submodul dari $A$, maka terdapat elemen tak nol $c \in R$ sehingga $c x \notin I$ Karena $I$ ideal dan $c x \notin I$, diperoleh $x \notin I$ kontradiksi dengan $x \in I$. Jadi, $x$ salah satu elemen pembangun $I$.

$(\Leftarrow)$ Karena $x$ pembangun dari $I$ sebagai $R$-submodul dari $A$, maka setiap elemen tak nol $r \in R$ dengan $0 \neq r x \in I$ berlaku $x \in I$ karena $I$ ideal dasar.

2. Ambil sebarang elemen-elemen tak nol $r_{i} \in R$ dan sebarang $x_{i} \in X$ dengan $i=1,2, \ldots, n$ dan $n \in$ $\mathbb{N}$, sedemikian sehingga $\sum_{i=1}^{n} r_{i} x_{i} \in I$. Akan ditunjukkan $x_{i}$ merupakan elemen pembangun $I$ sebagai $R$-submodul untuk setiap $i=1,2, \ldots, n$. Tanpa mengurangi keumuman bukti, andaikan terdapat $x_{j}$ dengan $1 \leq j \leq k$ untuk suatu $k \leq n$ sedemikian sehingga $x_{j}$ bukan elemen-elemen pembangun $I$ sebagai $R$-submodul. Artinya, terdapat elemen-elemen tak nol $c_{j} \in R, 1 \leq j \leq k$ sehingga $\sum_{j=1}^{k} c_{j} x_{j} \notin I$. Hal ini kontradiksi dengan yang diketahui. Jadi, haruslah $x_{i}$ merupakan elemenelemen pembangun $I$ sebagai $R$-submodul dan menurut sifat $1 ., x_{i} \in I$ untuk setiap $i=1,2, \ldots, n$ karena $I$ ideal dasar.

3. Karena $I$ merupakan ideal dasar, maka menurut 1., untuk setiap $x \in X$ sedemikian sehingga $0 \neq$ $r x \in I, x$ merupakan elemen pembangun dari $I$. Misalkan himpunan semua elemen di $X$ yang merupakan elemen pembangun $I$ dituliskan $X_{I}$ maka

$$
X_{I}=\{x \in X \mid r x \in I\}=\{x \in X \mid x \in I\}=X \cap I .
$$

Menurut poin 1. dan 2. diperoleh $I=\left\langle X_{I}\right\rangle$.

Perhatikan kembali Contoh 2.7, ideal dasar $I$ dalam aljabar $M$ merupakan $\mathbb{Z}$-subaljabar tak bebas, sehingga tidak mungkin ideal dasar I merupakan ideal bebas. Namun, ideal dasar nol merupakan 
$\mathbb{Z}$-subaljabar bebas dari aljabar tidak bebas $M$. Uraian ini menginspirasikan perumuman pengertian ideal bebas dalam Definisi 2.4.

\section{Definisi 2.9}

Diberikan $R$-aljabar $A=\langle X\rangle$ dengan $X \subset A$ dan $I$ ideal dari $A$. Ideal $I$ disebut ideal bebas (free ideal) jika $I$ merupakan $R$-submodul bebas dari $A$ dengan basisnya subset suatu pembangun dari $A$.

Berdasarkan Definisi 2.9, ideal nol selalu merupakan ideal bebas. Akan tetapi $R$-aljabar $A$ yang tidak bebas pasti bukan merupakan ideal bebas.

\section{Akibat 2.10}

Ideal bebas trivial dari $R$-aljabar tak bebas hanyalah ideal nol, sehingga ideal nol merupakan ideal bebas sekaligus ideal dasar.

Ideal-ideal $I, J$ dari aljabar $M$ pada Contoh 2.7, keduanya bukan merupakan $\mathbb{Z}$-submodul bebas dari $M$ maka kedua $I, J$ bukan ideal bebas. Artinya ideal $I$ merupakan ideal dasar tetapi bukan ideal bebas. Contoh 2.7 ini dapat sebagai contoh kontra tidak berlakunya Teorema 2.8 dalam [3], pada $R$ aljabar yang tidak bebas.

Contoh 2.11 Diberikan $\mathbb{Z}$-aljabar tak bebas $N=\left(\mathbb{Z}, \mathbb{Z}_{6}\right)=\langle\{(1,0),(0,1)\}\rangle$ maka:

1. Ideal $U=(\mathbb{Z}, 0)=\langle\{(1,0)\}\rangle$ merupakan ideal bebas sekaligus ideal dasar di $N$;

2. Ideal $V=(2 \mathbb{Z}, 0)=\langle\{(2,0)\}\rangle$ bukan ideal bebas dan bukan ideal dasar di $N$;

3. Ideal $W=\left(0, \mathbb{Z}_{6}\right)=\langle\{(0,1)\}\rangle$ adalah ideal dasar tetapi bukan ideal bebas.

Contoh 2.7 dan 2.11 mengisyaratkan hubungan antara ideal dasar dengan ideal bebas dalam $R$ aljabar tak bebas. Ideal bebas pasti merupakan ideal dasar tetapi tidak sebaliknya, merupakan sifat yang diperkuat oleh Lemma 2.8 dan Definisi 2.9.

\section{Teorema 2.12}

Diberikan $R$-aljabar $A=\langle X\rangle$ dengan $X \subset A$ dan $I$ ideal dari $A$. Jika $I$ ideal bebas maka $I$ merupakan ideal dasar.

Bukti: Ideal $I$ merupakan ideal bebas dari $A=\langle X\rangle$ maka menurut Definisi 2.9, $I$ merupakan $R$ submodul bebas dengan $I=\langle Y\rangle$ untuk suatu $Y \subset X$ dengan $Y$ bebas linear. Ambil sebarang elemen tak nol $r \in R$ dan sebarang $x \in X$ sedemikian sehingga $0 \neq r x \in I$ maka berdasarkan Lemma 2.8, $x \in Y$, sehingga $x=1_{R} x \in I$ Jadi, $I$ ideal dasar.

Beberapa sifat dari ideal dasar dalam $R$-aljabar bebas dibuktikan dengan ideal bebas, karena keduanya ekuivalen. Akan tetapi menurut Teorema 2.12, ideal bebas dalam $R$-aljabar tak bebas hanya merupakan syarat perlu dan bukan syarat cukup dari ideal dasar, dengan contoh kontranya Contoh 2.11 poin 3. Ketidakekuivalennya ideal dasar dan ideal bebas merupakan salah satu sifat yang tidak bertahan pada $R$-aljabar tak bebas, sehingga beberapa sifat ideal dasar tidak dapat dibuktikan dengan ideal bebas. Salah satu sifat ideal dasar tersebut adalah ideal dasar prima.

\section{Ideal Dasar Prima dan Beberapa Sifatnya}

Berdasarkan [6] dan [7], ideal $P$ merupakan ideal prima dari ring (aljabar) unital $A$ jika $P \neq A$ dan untuk setiap ideal-ideal $I, J \subseteq A$. Jika $I J \subseteq A$ maka $I \subseteq A$ atau $J \subseteq A$. Secara analog, ideal dasar prima dalam aljabar unital dapat didefinisikan.

\section{Definisi 3.1}

Diberikan $R$-aljabar unital $A$. Ideal dasar $P \subsetneq A$ disebut ideal dasar prima (prime basic ideal) jika setiap ideal dasar $I, J \subseteq A$, jika $I J \subseteq A$ maka $I \subseteq P$ atau $J \subseteq P$. 
Definisi 3.1 ini merupakan perumuman ideal dasar prima dalam $R$-aljabar bebas ([2]). Jelas ideal prima belum tentu merupakan ideal dasar prima karena idealnya belum tentu ideal dasar. Sebagai contoh, ideal prima $3 \mathbb{Z}$ dalam aljabar $\mathbb{Z}$ atas dirinya sendiri, bukan merupakan ideal dasar. Namun, ideal dasar prima juga belum tentu ideal prima.

Contoh 3.2 Diberikan $\mathbb{Z}$-aljabar $N$ pada Contoh 2.11, maka ideal-ideal dasar tak nol dari $N$ hanyalah $U=(\mathbb{Z}, 0), W=\left(0, \mathbb{Z}_{6}\right)$.

1. Ideal dasar $U$ adalah prima, tetapi $U$ bukan ideal prima karena $\left(0,2 \mathbb{Z}_{6}\right)\left(0,3 \mathbb{Z}_{6}\right)=\{(0,0)\} \subset U$ dan $\left(0,2 \mathbb{Z}_{6}\right) \not \subset U,\left(0,3 \mathbb{Z}_{6}\right) \not \subset U$;

2. Ideal $W$ merupakan ideal dasar prima sekaligus ideal prima;

3. Karena $U W=\{(0,0)\}$ maka ideal nol dalam $N$ bukan ideal dasar prima sekaligus bukan ideal prima.

Catatan 3.3 Keprimaan ideal dan ideal dasar dalam $R$-aljabar $A$ tidak saling mempengaruhi. jika diambil $Y \subset X$ dengan $X$ pembangun $R$-aljabar tak bebas $A$ maka $R$-submodul yang dibangun oleh $Y,\langle Y\rangle=\{r y \mid r \in R, y \in Y\}$ belum tentu merupakan ideal dari $A$. Sebagai contoh, $\left\langle\left(\begin{array}{ll}1 & 0 \\ 0 & 0\end{array}\right)\right\rangle=$ $\left(\begin{array}{cc}\mathbb{Z}_{6} & 0 \\ 0 & 0\end{array}\right)$ adalah $\mathbb{Z}$-submodul sekaligus $\mathbb{Z}$-subaljabar yang bukan ideal dari $M$ pada Contoh 2.7 . Submodul tersebut dibangun oleh singleton $\left\{\left(\begin{array}{ll}1 & 0 \\ 0 & 0\end{array}\right)\right\}$. Telah diketahui bersama bahwa $R$-aljabar $A$ merupakan ring, sehingga untuk setiap $p \in A$ dapat didefinisikan ideal (dua sisi) yang dibangun oleh $p$, yaitu:

$$
(p)=\left\{\sum_{i} a_{i} p b_{i} \mid a_{i}, b_{i} \in A\right\}
$$

Contoh 3.4 Diberikan $\mathbb{Z}$-aljabar $M$ pada Contoh 2.7 dan $N$ pada Contoh 2.11 .

1. $\left(\begin{array}{ll}1 & 0 \\ 0 & 0\end{array}\right),\left(\begin{array}{ll}2 & 0 \\ 0 & 0\end{array}\right) \in M$ dengan $\left(\begin{array}{ll}1 & 0 \\ 0 & 0\end{array}\right) \in X,\left(\begin{array}{ll}2 & 0 \\ 0 & 0\end{array}\right) \notin X$. Menurut persamaan (1), diperoleh idealideal dari $M$ berikut:
a. $\left(\left(\begin{array}{ll}1 & 0 \\ 0 & 0\end{array}\right)\right)=\left(\begin{array}{cc}\mathbb{Z}_{6} & \mathbb{Z}_{6} \\ 0 & 0\end{array}\right)=I$ merupakan ideal dasar, dengan $\left(\left(\begin{array}{l}1 \\ 0\end{array}\right.\right.$

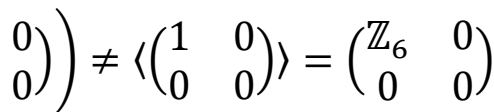
b. $\left(\left(\begin{array}{ll}2 & 0 \\ 0 & 0\end{array}\right)\right)=\left(\begin{array}{cc}2 \mathbb{Z}_{6} & 2 \mathbb{Z}_{6} \\ 0 & 0\end{array}\right)=J^{\prime}$ bukan ideal dasar dengan $\left(\left(\begin{array}{ll}2 & 0 \\ 0 & 0\end{array}\right)\right.$
$0)) \neq\left\langle\left(\begin{array}{ll}2 & 0 \\ 0 & 0\end{array}\right)\right\rangle=\left(\begin{array}{cc}2 \mathbb{Z}_{6} & 0 \\ 0 & 0\end{array}\right)$.

2. $\langle(1,0)\rangle=((1,0))=U,\langle(0,1)\rangle=((0,1))=W$, keduanya ideal dasar dalam $N$ yang dibangun oleh elemen pembangun dalam $\mathbb{Z}$-modul.

Membangun dalam aljabar $A$ sebagai ring, sangat jelas bedanya dengan membangun dalam aljabar $A$ sebagai $R$-modul. Contoh 3.4 poin 1.a., ideal (dua sisi) yang dibangun oleh $\left(\begin{array}{ll}1 & 0 \\ 0 & 0\end{array}\right) \in X$ merupakan ideal dasar. Karena $\left(\begin{array}{ll}0 & 1 \\ 0 & 0\end{array}\right)=\left(\begin{array}{ll}1 & 0 \\ 0 & 1\end{array}\right)\left(\begin{array}{ll}1 & 0 \\ 0 & 0\end{array}\right)\left(\begin{array}{ll}0 & 1 \\ 0 & 0\end{array}\right)$ maka $\left(\begin{array}{ll}0 & 1 \\ 0 & 0\end{array}\right) \in I$ akibatnya $k\left(\begin{array}{ll}0 & 1 \\ 0 & 0\end{array}\right)=$ $\left(\begin{array}{cc}0 & (k)_{6} \\ 0 & 0\end{array}\right) \in I$ untuk setiap $k \in \mathbb{Z}$. Akan tetapi $\left(\begin{array}{ll}0 & 0 \\ 0 & 1\end{array}\right) \neq\left(\begin{array}{ll}a & b \\ 0 & c\end{array}\right)\left(\begin{array}{ll}1 & 0 \\ 0 & 0\end{array}\right)\left(\begin{array}{ll}p & q \\ 0 & r\end{array}\right)$ untuk setiap $\left(\begin{array}{ll}a & b \\ 0 & c\end{array}\right),\left(\begin{array}{ll}p & q \\ 0 & r\end{array}\right) \in M$ maka $\left(\begin{array}{ll}0 & 0 \\ 0 & 1\end{array}\right) \notin I$ dan untuk setiap $k \in \mathbb{Z}$, jika $k\left(\begin{array}{ll}0 & 0 \\ 0 & 1\end{array}\right) \neq\left(\begin{array}{ll}0 & 0 \\ 0 & 0\end{array}\right)$ berakibat $k\left(\begin{array}{ll}0 & 0 \\ 0 & 1\end{array}\right)=\left(\begin{array}{cc}0 & 0 \\ 0 & (k)_{6}\end{array}\right) \notin I$. Berdasarkan Lemma 2.8, pembangun ideal dasar $I=\left(\begin{array}{cc}\mathbb{Z}_{6} & \mathbb{Z}_{6} \\ 0 & 0\end{array}\right)=$ $\left(\left(\begin{array}{ll}1 & 0 \\ 0 & 0\end{array}\right)\right)$ sebagai submodul adalah $\left\{\left(\begin{array}{ll}1 & 0 \\ 0 & 0\end{array}\right),\left(\begin{array}{ll}0 & 1 \\ 0 & 0\end{array}\right)\right\} \subset X$. Secara sama, kedua ideal dari Contoh 
2.7, $\left(\left(\begin{array}{ll}0 & 1 \\ 0 & 0\end{array}\right)\right)=\left(\begin{array}{cc}0 & \mathbb{Z}_{6} \\ 0 & 0\end{array}\right)=\left\langle\left(\begin{array}{ll}0 & 1 \\ 0 & 0\end{array}\right)\right\rangle \operatorname{dan}\left(\left(\begin{array}{ll}0 & 0 \\ 0 & 1\end{array}\right)\right)=\left(\begin{array}{ll}0 & \mathbb{Z}_{6} \\ 0 & \mathbb{Z}_{6}\end{array}\right)=\left\langle\left\{\left(\begin{array}{ll}0 & 1 \\ 0 & 0\end{array}\right),\left(\begin{array}{ll}0 & 0 \\ 0 & 1\end{array}\right)\right\}\right\rangle$ merupakan ideal dasar.

\section{Lemma 3.5}

Diberikan $R$-aljabar $A=\langle X\rangle$ dengan $X \subset A$. Jika $x \in X$ maka ideal yang dibangun oleh $x$, yakni $(x)$ merupakan ideal dasar.

Bukti: Jika $x \in X \subset A$ maka $x=1_{A} x 1_{A} \in(x)$ sehingga $X \cap(x) \neq \emptyset$. Karena $(x)$ ideal dari $R$-aljabar $A$ maka $(x)$ merupakan $R$-submodul, sehingga setiap $r \in R, r x \in(x)$ yang berarti $x$ merupakan salah satu elemen pembangun $(x)$ atas $R$. Ambil sebarang $Y$ sedemikian sehingga $(x)=\langle Y\rangle$. Ambil sebarang elemen tak nol $k \in R, y \in Y$ dengan $y \notin(x), k y \neq 0$ maka akan ditunjukkan bahwa $k y \notin(x)$. Karena $y \notin(x)$ maka $y \neq \sum_{i=1}^{m} a_{i} x b_{i}$ untuk setiap $a_{i}, b_{i} \in A, 1 \leq i \leq m$ dan $m \in \mathbb{N}$. Karena $k y \neq 0$ maka $k y \neq k \sum_{i=1}^{m} a_{i} x b_{i}=\sum_{i=1}^{m}\left(k a_{i}\right) x b_{i} \in(x)$ dengan $k a_{i}, b_{i} \in A, 1 \leq i \leq m$. Terbukti bahwa $k y \notin(x)$. Jadi, untuk setiap elemen tak nol $k \in R, y \in Y$, jika $0 \neq k y \in(x)$ maka $y \in(x)$ dengan kata lain, $(x)$ ideal dasar.

Beberapa bukti sifat ideal dasar prima dalam $R$-aljabar bebas dalam [2] menggunakan ideal bebas. Ideal dasar yang dibangun oleh suatu elemen dalam aljabar sebagai ring, juga dapat digunakan untuk menyelidiki dan membuktikan keprimaan suatu ideal dasar.

\section{Teorema 3.6}

Diberikan $R$-aljabar unital $A$, dan ideal dasar $P \subset A$, maka ketiga pernyataan di bawah ini ekuivalen:

1. Ideal dasar $P$ adalah prima.

2. Untuk setiap $a, b \in A$ dengan ( $a)$, (b) ideal-ideal dasar di $A$, jika $(a)(b) \subseteq P$ maka $a \in P$ atau $b \in P$.

3. Untuk setiap $a, b \in A$ dengan ( $a$ ), (b) ideal-ideal dasar di $A$, jika $a A b \subseteq P$ maka $a \in P$ atau $b \in$ $P$.

Bukti: $(1 \Rightarrow 2)$ Ambil sebarang $a, b \in A$ sedemikian sehingga $(a),(b)$ ideal-ideal dasar di $A$. Karena $P$ ideal dasar prima dan $(a)(b) \subseteq P$, maka menurut Definisi 2.9, $(a) \subseteq P$ atau $(b) \subseteq P$. Di sisi lain, $a=1_{A} a 1_{A} \in(a), b=1_{A} b 1_{A} \in(b)$ sehingga diperoleh $a \in P$ atau $b \in P$. Kedua, akan ditunjukkan (2 $\Rightarrow 3$ ), ambil sebarang $a, b \in A$ sedemikian sehingga $(a),(b)$ ideal-ideal dasar di $A$. jika $a A b \subseteq P$ maka tampak jelas bahwa setiap $a x b \in a A b$ berlaku axb=(1 $a x)\left(1_{A} b 1_{A}\right) \in(a)(b) \subseteq P$. Berdasarkan hipotesis, diperoleh $a \in P$ atau $b \in P$. Terakhir, dibuktikan $(3 \Rightarrow 1)$. Ambil sebarang idealideal dasar $I, J$ di $A$ sedemikian sehingga $I J \subset P$, dan $I \not \subset P$. Menurut Lemma $2.8, I=\left\langle X_{I}\right\rangle, J=\left\langle X_{J}\right\rangle$ dengan $X_{I}=X \cap I, X_{J}=X \cap J$ sehingga terdapat elemen pembangun $u \in X_{I} \subset I, u \notin P$. Berdasarkan Lemma 3.5, ( $u$ ) ideal dasar dan untuk setiap $v \in X_{J} \subset J,(v)$ juga ideal dasar. Di sisi lain, $u A v \subset$ $I J \subset P$ sehingga berdasarkan hipotesis diperoleh $v \in P$ untuk setiap $v \in X_{J}$. Ambil sebarang $x \in J$, maka terdapat $k_{j} \in R, v_{j} \in X_{J} 1 \leq j \leq m$ sehingga $x=\sum_{j=1}^{m} k_{j} v_{j} \in P$. Diperoleh bahwa $J \subset P$. Jadi, $P$ ideal dasar prima.

Teorema 3.6 adalah syarat perlu dan cukup ideal dasar prima dalam $R$-aljabar $A$, yang tidak berubah dengan adanya generalisasi dari aljabar bebas. Perbedaan utama pembuktian syarat perlu dan cukup ideal dasar prima dalam aljabar bebas pada [2,Proposisi 3.4], terletak pada peran ideal bebas karena ekuivalen dengan ideal dasar pada bukti $(3 \Rightarrow 1)$. Tampak bahwa bukti Teorema 3.6 tidak menggunakan ideal bebas tetapi cukup pembangunnya yang belum tentu bebas linear. Teorema 3.6 memberikan kemudahan dalam menyelidiki suatu ideal dasar apakah prima atau tidak. Sebagai contoh, Ideal nol di $N$ bukan ideal dasar prima karena $((1,0)),((0,1))=\{(0,0)\}$. Demikian pula, ideal nol di $M$ juga tidak prima karena terdapat $a=\left(\begin{array}{ll}0 & 1 \\ 0 & 0\end{array}\right)$ sehingga $a M a=\left\{\left(\begin{array}{ll}0 & 0 \\ 0 & 0\end{array}\right)\right\}$. 


\section{Kesimpulan}

Diberikan $R$-aljabar unital $A$ atas ring komutatif $R$ dengan elemen satuan. Ideal dasar dalam $R$-aljabar bebas merupakan syarat perlu dan cukup ideal bebas. Akan tetapi, ideal dasar hanya merupakan syarat perlu ideal bebas dalam $R$-aljabar tak bebas. Secara umum, ideal bebas pasti merupakan ideal dasar tetapi tidak sebaliknya.

Ideal prima dan ideal dasar prima dalam $R$-aljabar $A$ didefinisikan secara analog, namun keduanya tidak saling bergantung. Artinya, ideal prima belum tentu ideal dasar prima dan sebaliknya ideal dasar prima juga belum tentu ideal prima. Ideal dasar yang dibangun oleh suatu elemen dalam aljabar sebagai ring dapat mengkarakterisasi ideal dasar prima. Hasil utama dalam artikel ini adalah Teorema 3.6. yaitu syarat perlu dan cukup dari ideal dasar prima dalam $R$-aljabar $A$. Pembuktian teorema ini tidak melibatkan ideal bebas, tetapi menggunakan peran dari pembangun ideal dasar yang dipandang sebagai submodul. Kajian dapat dilanjutkan pada karakteristik ideal dasar yang lain maupun sifat aljabar berdasarkan ideal dasarnya.

\section{Ucapan Terimakasih}

Terimakasih kepada LPPM UIN Sunan Kalijaga Yogyakarta yang telah mendanai penelitian Klaster Research Leader Nasional tahun 2018. Artikel ini merupakan bagian dari hasil penelitian tersebut.

\section{Referensi}

[1] K. Wardati, I.E. Wijayanti, S. Wahyuni, 2012, Ideal Mendasar dalam Aljabar Lintasan Leavitt, Prosiding pada Konferensi Nasional Matematika XVI, Jurusam Matematika Universitas Padjadjaran, Bandung, Indonesia, 75-84.

[2] K. Wardati, I.E. Wijayanti, S. Wahyuni, 2014, On Primeness of Path Algebras over a Unital Commutative Ring, JP. Journal of Algebra, Number Theory and Applications, 34(2), 121-138

[3] K. Wardati, I.E. Wijayanti, S. Wahyuni, 2015, On Free Ideals In Free Algebras Over A Commutative Ring, J. Indones. Math. Soc, 21 (1)\}, 59-69.

[4] M. Tomforde, 2011, Leavitt Path Algebras with Coefficient in a Commutative Ring, J. Pure. Appl. Algebra, 215, 471484.

[5] P. A. Grillet, 2007, Abstract Algebra, Graduated Texts in Mathematics, Spinger-Verlag, New York.

[6] R. Wisbauer, 1991, Foundations of Module and Ring Theory, A Handbook for Study and Research, University of Dusseldorf, Gordon and Breach Publisher.

[7] T.Y. Lam, 1991, A First Course in Noncommutative Rings, Springer-Verlag, New York.

[8] W.A. Adkins, S.S. Weintraub, 1999, Algebra an Approach Via Module Theory, Springer-Verlag NewYork, 1999. 